\title{
CUANDO EL REY FRANCISCO DE ASÍS PERDIÓ EL AURA REGIA. CARICATURA Y VIDA COTIDIANA EN EL PARÍS DEL SEGUNDO IMPERIO (1868-1870)
}

\author{
Carlos Reyero \\ (Universidad Autónoma de Madrid) \\ carlosreyerohermosilla@gmail.com
}

\section{RESUMEN}

Este trabajo analiza las caricaturas del rey Francisco de Asís, marido de la reina Isabel II de España, la mayor parte publicadas en revistas españolas inmediatamente después de su destronamiento en 1868. El estudio se centra en el contexto histórico, con objeto de demostrar que los dibujantes tuvieron en cuenta su vida cotidiana en París. Se inspiraron en sus ideas y venidas a través de la prensa (tanto española como francesa). Este estudio es también una oportunidad para revisar, con nuevos datos documentales, el periodo crucial de dos años que los monarcas pasaron en París antes de la caída del Segundo Imperio. El propósito principal es averiguar cuales fueron los aspectos más risibles de su personalidad y, en segundo término, cómo se reflejaron en la caricatura.

PALABRAS CLAVE: Francisco de Asís; Monarquía; Exclusión política; Imaginario social; Humor.

\section{WHEN KING FRANCISCO DE ASSIS LOST HIS ROYAL AURA. CARICATURE AND EVERYDAY LIFE IN SECOND EMPIRE PARIS} (1868-1870)

\begin{abstract}
This paper analyses caricatures of King Francisco de Assis, husband of Queen Isabella II of Spain, mostly published in Spanish journals just after his dethronement in 1868. The study focuses on the historical context to prove that cartoonists took account of his everyday life in Paris. They got inspired by his comings and goings through the press (both Spanish and French). This essay is also an opportunity to revisit, with new documentary data, the crucial two-year period that the monarchs spent in Paris before the fall of Second Empire. The main purpose is to find out which were the most laughable aspects of his personality, and, secondly, how they are reflected in caricature.
\end{abstract}

KEYWORDS: King Francisco de Assis; Monarchy; Political exclusion; Social Imaginary; Humour. 
Distintas investigaciones se han ocupado de las caricaturas producidas en España contra el régimen de Isabel II, en particular de la serie «Los Borbones en pelota», en las que tiene una relevante presencia el rey consorte ${ }^{1}$. El objetivo de este trabajo es, por un lado, reflexionar específicamente sobre los procedimientos visuales de su caracterización como individuo, con referencias a esas y a otras caricaturas publicadas en distintos soportes tras la caída del régimen; y, por otro, confrontarlas con noticias de su vida cotidiana en el exilio, cuando el exrey se presenta ante la opinión pública, francesa y española, con una forma de vida distinta de la que había llevado hasta entonces. Esta nueva sociabilidad implica, en última instancia, la pérdida del aura regia, al menos tal y como se había entendido hasta entonces. Los datos manejados proceden, unos, de fuentes archivísticas, que suministran informaciones poco conocidas o mal trasmitidas sobre su paso por la capital francesa durante los últimos años del Segundo Imperio; otros han sido extraídos de la prensa de París, donde se estableció, junto al resto de miembros de la Familia Real, así como de la prensa española. Se pretende con ello precisar la trayectoria seguida por el exrey entre 1868 y 1870 y el uso que de ella pudieron hacer los dibujantes satíricos.

Se trata de aplicar un método comparativo que ponga en relación hechos históricos coetáneos con invenciones caricaturescas, en el momento álgido de la crítica hacia su figura pública. La intención última es desentrañar qué grado de aproximación existió entre el conocimiento de la realidad y la construcción de una imagen distorsionada del personaje. Se pretende averiguar, en definitiva, cuales son y por qué los puntos más risibles de su personalidad y de su comportamiento que atraen al imaginario público, y cómo los procedimientos de la risa y de la burla condicionan el modo de caricaturizar.

Como se sabe, la Familia Real partió para su exilio en Francia desde San Sebastián, donde se encontraba de veraneo, el 30 de septiembre de 1868. Unos meses después, la revista satírica Gil Blas aludía al momento, ambientado en aquella ciudad, en el que un militar advertía a los reyes del hundimiento del régimen, como consecuencia de la derrota de las tropas gubernamentales en Alcolea. Acompañados

\footnotetext{
${ }^{1}$ Es la segunda figura más representada, después de la reina: aparece hasta treinta y seis veces. Isabel Burdiel (ed.), Sem. Los Borbones en pelota (Zaragoza: Institución Fernando el Católico, 2012), 61. Sobre el tema véase: Robert Pageard, Lee Fontanella y María Dolores Cabra Loredo (eds.), Sem. Los Borbones en pelota (Madrid: El Museo Universal, 1991); Jesús Rubio, "En torno a la autoría y a la primera difusión de 'Los Borbones en pelota'," El Gnomo. Boletín de estudios becquerianos 3 (1994): 65-91; María Dolores Cabra Loredo. "Sem y el burdel imaginario. Un estudio sobre los borbones en pelota," en Estudios de literatura española de los siglos XIX y XX. Homenaje a Juan María Díez Taboada (Madrid: CSIC, 1998), 38-46; Begoña Regueiro Salgado. "Los 'Borbones en pelota' y los Bécquer. Revisión crítica de su posible relación," en Campus Stellae. Haciendo caminos en la investigación literaria, ed. Dolores Fernández López y otros (Santiago de Compostela: Universidad, 2006), 206-213; Mercedes Alcalá Galán. "Stupeur et tremblements. Estática de lo obsceno en 'Los Borbones en pelota'," en Venus Veneranda II. Literatura erótica y modernidad en España, ed. Adrienne L. Martin y José Ignacio Díez (Madrid: Universidad Complutense, 2008), 53-78; Jesús Rubio Jiménez y Javier Urbina. "Imagen y política: el inquietante mundo de SEM," en Simposio sobre Literatura Popular 2011. Imágenes e Ideas: La Imaginatura (Valladolid: $\quad$ Fundación Joaquín Díaz, $\quad 2012), \quad$ 104-188, https:// funjdiaz.net/imagenes/actas/2011literatura.pdf, consultado el 20 de mayo de 2019.
} 
del padre Claret, el todavía rey Francisco de Asís aparece encogido, en segundo término, aterrado por la situación (fig. 1) ${ }^{2}$.

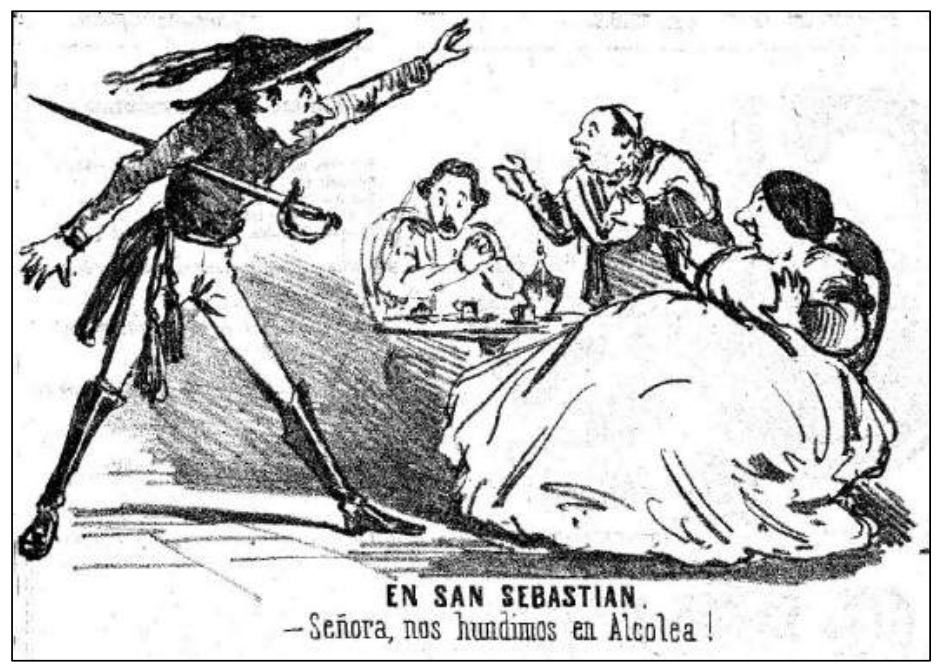

Fig. 1- Francisco Ortego, En San Sebastián, Gil Blas, 24 de diciembre de 1868

Durante las cinco semanas que pasaron en el castillo de $\mathrm{Pau}^{3}$ aprovecharon para organizar su establecimiento en París ${ }^{4}$. El primer problema que hubieron de resolver, como cualquier familia burguesa, fue el de la vivienda. El 26 de octubre de 1868 los reyes, todavía en el departamento de los Pirineos Atlánticos, firmaron un poder a favor del conde de Oñate, jefe de Gastos y Oficios de la Casa Real, con objeto de que este gestionase el alquiler de una vivienda en la capital francesa adecuada a sus necesidades ${ }^{5}$. Dos días después, el 28 de octubre, se suscribía en París un contrato entre los reyes, representados por Oñate, y Jeanne-Marguerite-Zoé Michon de Pierreclau, viuda del barón de Montailleur-Ruffo, por el cual esta les alquilaba durante un año entero, a partir del 1 de enero de 1869, un hotel situado en el número 68 de la avenida de los Campos Elíseos, así como algunas dependencias del hotel contiguo que la propietaria se reservaba para su uso ${ }^{6}$. Cuando la prensa

\footnotetext{
${ }^{2}$ Gil Blas, 24 de diciembre de 1868.

${ }^{3}$ María José Vilar García, "El primer exilio de Isabel II visto desde la prensa vasco-francesa (Pau, septiembre-noviembre 1868)," Historia Contemporánea $44 \quad$ (2012): 242-279, http://www.ehu.eus/ojs/index.php/HC/article/view/6614/6052, consultado el 20 de mayo de 2019. Véase también : Théodor Chastang, Notice historique sur le château de Pau (Pau : 1869), 56-57.

${ }^{4}$ Además de otros trabajos de la autora, véase: Isabel Burdiel. "Historia de una desactivación: el exilio parisino de Isabel II (1868-1904)," en El exilio español durante los siglos XIX y XX, ed. Fernando Martínez, Jordi Canal y Encarnación Lemus (Madrid: Sociedad Estatal de Conmemoraciones Culturales-Marcial Pons, 2010): 55-84.

${ }^{5}$ Ante el notario Charles Beigbeder de Jurançon, localidad contigua a Pau, el 26 de octubre de 1868. Archives Nationales MC/ET/II/1151. En el documento, la reina firma por delante del rey, lo que no sucede en otros documentos posteriores.

${ }^{6}$ El hotel contaba con planta baja y cuatro pisos, además de un pabellón de portería a la entrada, caballerizas y hangar. El alquiler incluía un pabellón entre el hotel contiguo, un pabellón en el jardín y los hangares de este. El contrato fue firmado por el conde Oñate, que se hospedaba en el hotel Belfort,
} 
española anuncia el traslado, desde Pau a París, de la Familia Real, para cuya instalación provisional habían reservado el Pavillon de Rohan en la rue de Rivoli antes de emprender el viaje, se hace también eco de «los hoteles que han tomado en los Campos Elíseos», lo que demuestra un conocimiento público de ese contrato ${ }^{7}$. Un cronista llega a confundir ambas informaciones y dice que los reyes residirán en el hotel de Montailleur durante cinco semanas ${ }^{8}$.

La Familia Real, con toda su corte de servidores, llega a París el sábado 7 de noviembre de 1868. Se instalan, como tenían previsto, en el número 172 de la rue de Rivoli, que se corresponde con una «maison meublée» conocida como el Pavillon de Rohan'. La estancia tiene carácter provisional, «ínterin se terminan los preparativos en los hoteles alquilados en los Campos Elíseos» ${ }^{10}$, aunque se prolongó durante varios meses, sin que se tenga constancia de que llegasen a habitar esos hoteles que habían alquilado para todo el año 1869. La razón no fue otra que la adquisición de una mansión en la avenue du Roi de Rome, hoy avenue Kléber, seguramente por una oportunidad inesperada que se presentó. En efecto, el 14 de diciembre de 1868 se firmó el contrato de compraventa del hotel Basiliewski mediante una «déclaration de commandi, en la que actuó como intermediario, Edmont About, con objeto de ocultar la identidad de los compradores. Significativamente, en el documento de compra, el rey firma por delante de la reina ${ }^{11}$. En París, los maridos están por encima de las señoras.

La noticia se recoge en la prensa de los días posteriores, incluyendo alguna anécdota, como la sorpresa que se llevaron Isabel y Francisco de Asís al ver tanta gente cuando entraron en el salón del notario, donde confirmaron la compra, que se resolvió en diez minutos ${ }^{12}$.

situado en el número 15 la rue de l'Arcade, que pagó 35.000 francos de los 70.000 que costaba el alquiler. Como el conde no sabía francés, le fueron traducidos los documentos por el secretario de la embajada española. El contrato se firmó ante el notario Charles Saint-Ange Berceon (Archives Nationales MC/ET/II/1151)

${ }^{7}$ La Época, 2 de noviembre de 1868.

${ }^{8}$ La Regeneración, 3 de noviembre de 1868

${ }_{9}^{9}$ No debe confundirse, como sucede en ocasiones, con el homónimo Pabellón de Rohan que forma parte del Palacio de Louvre, sino de un establecimiento hotelero. Véase: Karl Baedeker, Paris. Guide pratique du voyageur (París: 1860), 7. Al parecer, se trataba de un inmueble de cinco plantas, la primera de las cuales fue ocupada por la reina y sus hijos (Vilar, "El primer exilio", 269). Una litografía titulada Paris moderne. Les Tuileries, le Louvre et la rue de Rivoli de esos años permite ver las construcciones frente al Louvre (Bibliothèque Nationale de France, département Estampes et photographie, RESERVE FT 4-QB-370 (153); http:/ / catalogue.bnf.fr/ark:/12148/cb38793157h).

${ }^{10}$ La Discusión, 10 de noviembre de 1868.

${ }^{11}$ El documento recoge la ubicación precisa del edificio, sus límites y la adquisición del terreno por parte de Alexandre de Basiliewski el 29 de junio de 1864, así como el consentimiento de su esposa, Olga Bachsnéteff. Se fijó un precio de 130.000 francos más las cargas hipotecarias con las que contaba. Estas cargas fueron canceladas en fechas posteriores: la primera, por 8.000 francos, el 19 de junio y el 1 de julio de 1869 a un tal Mr. Fleury (compareció Salvador de Albacete, gentilhombre de S.M. la Reina); el 28 de julio y el 8 de agosto de 1870, por 18.000 francos, a Celestine Chapuis, viuda de Louis Auguste Masson; y el 31 de agosto de 1878, por valor de 40.000 francos al hijo de Mr. Fleury (compareció Gustave Loiré) (Archives Nationales MC/ET/II/1151).

12 "Una veintena de personas, en efecto, estaban allí, y los compradores pudieron creer que era una costumbre francesa nacida de un exceso de desconfianza". Entre esos curiosos estaba "un joven 


\section{UN HOMBRE IRRELEVANTE, SIMPLE Y DÉBIL NO MERECE SER REY}

Aunque, en general, el imaginario que se configura del rey Francisco de Asís en Francia, tras anunciarse su casamiento con Isabel II, es el de un individuo distinguido, cabe llamar la atención sobre una ilustración que, tan solo un mes después de celebrarse el matrimonio, se publica en Le Charivari (fig. 2). Allí se le presenta como un hombre temeroso y resignado, «con un sombrero de algodón en la cabeza y una vela en la mano», después de haber visto como huye por la ventana su hermano don Enrique. Forma parte de un cuento titulado «Romancero Conjugal» [sic], que imagina una relación entre este y la reina, que, acaba por rechazarlo, mientras en la calle se comenta: «La reina se casa con su primo don Francisco que tiene voz de mujer» ${ }^{13}$.

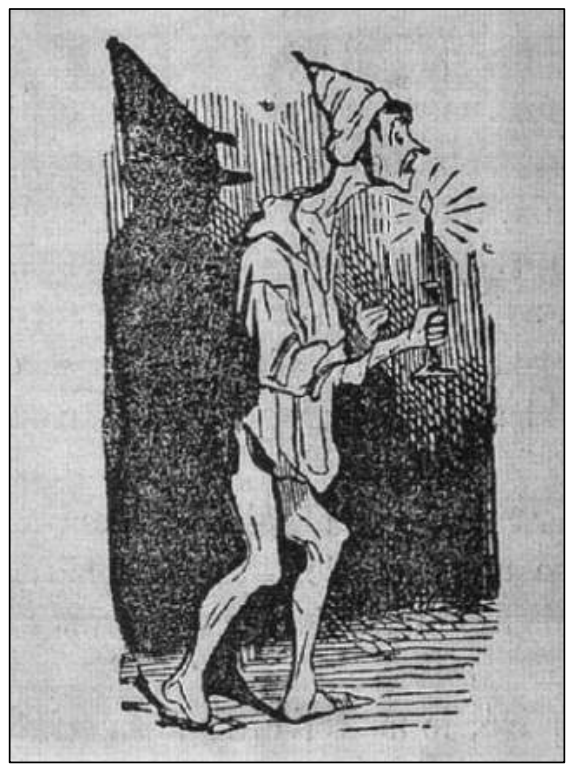

Fig. 2- Caricatura de Francisco de Asís, Le Charivari, 6 de septiembre de 1846.

Por lo tanto, las formas de ridiculización literaria y visual que proliferan después de 1868 han de considerarse en relación con un clima precedente que, en Francia, se constata desde el mismo momento en que el personaje aparece en la escena pública.

En las caricaturas que aluden, de una u otra manera, a los primeros meses del exilio, se consolida la idea de que, en el marco de la Familia Real, Francisco de Asís no tiene capacidad de decisión, es decir, carece tanto de verdadero poder como de

periodista de muy pequeña talla, que la reina reconoció, aseguró él, después”, sin dar más detalles. Irónicamente el cronista anota que "la reina dijo que su causa ganaba terreno" (Le Gaulois, 21 de diciembre de 1868).

${ }^{13}$ Le Charivari, 6 de septiembre de 1846. Como se sabe, don Enrique de Borbón, duque de Sevilla, fue uno de los pretendientes al trono. 
cualquier posibilidad de imponer su voluntad; es simple -se comporta de manera boba, sin personalidad-; y su presencia física es irrelevante, derivada de su baja estatura, rasgo que se acentúa. En la medida en que la energía, la sagacidad y el porte distinguido son rasgos esenciales de un monarca moderno, Francisco de Asís se presenta como la antítesis. En Francia suele recordarse que, a pesar de su condición de rey, carecía de cualquier capacidad de intervención en asuntos políticos. Es significativo que periódicos prestigiosos como Le Figaro contribuyeran a alimentar ese imaginario, aunque no deje de subrayarse la bonhomía que se aprecia en su mirada y en su sonrisa y «su admiración inteligente hacia las obras de arte, preferentemente la pintura». Sin embargo, «el rey es pequeño, de baja estatura y redondeado [...]; se diría un jorobado sin chepa, todo él flotando en un paletó fuera de tallaje, de color avellana». Por si fuera poco, se incide en percepciones sensoriales no visuales de carácter negativo, tanto olfativas como acústicas. Así, se habla de la "pomada de olor agresivo que pretende provocar a las narices más descuidadamente indiferentes», con la que trata de domar «sus cabellos un poco encrespados, del color de su paletó»; y, sobre todo, de su voz, «que envidiarían los corifeos de la capilla Sixtina» ${ }^{14}$. Francisco Ortego le caracteriza expresamente como Juan Lanas, sinónimo de hombre pusilánime y de poco carácter, que luce las condecoraciones militares sin ninguna convicción (fig. 3$)^{15}$.

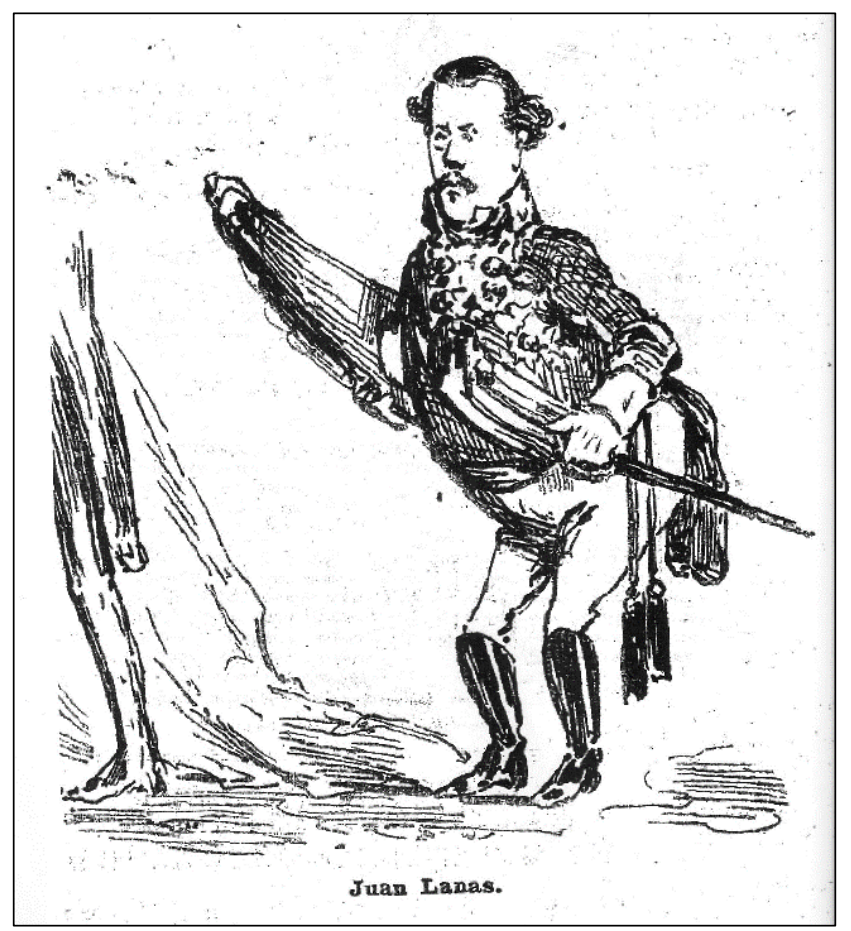

Fig. 3- Francisco Ortego, Juan Lanas, Gil Blas, 27 de mayo de 1869

\footnotetext{
14 Le Figaro, 18 de abril de 1869.

15 Gil Blas, 27 de mayo de 1869.
} 
Esta personalidad ridícula se pone de manifiesto, a través de la caricatura, en las situaciones más decisivas por las que pasa. Por ejemplo, en el momento de cruzar la frontera, donde se le presenta como el último títere de la comitiva ${ }^{16}$; o en una entrevista de González Bravo con Olózaga, embajador de España en París, donde se sitúa en segundo término, desdibujado (fig. 4$)^{17}$.

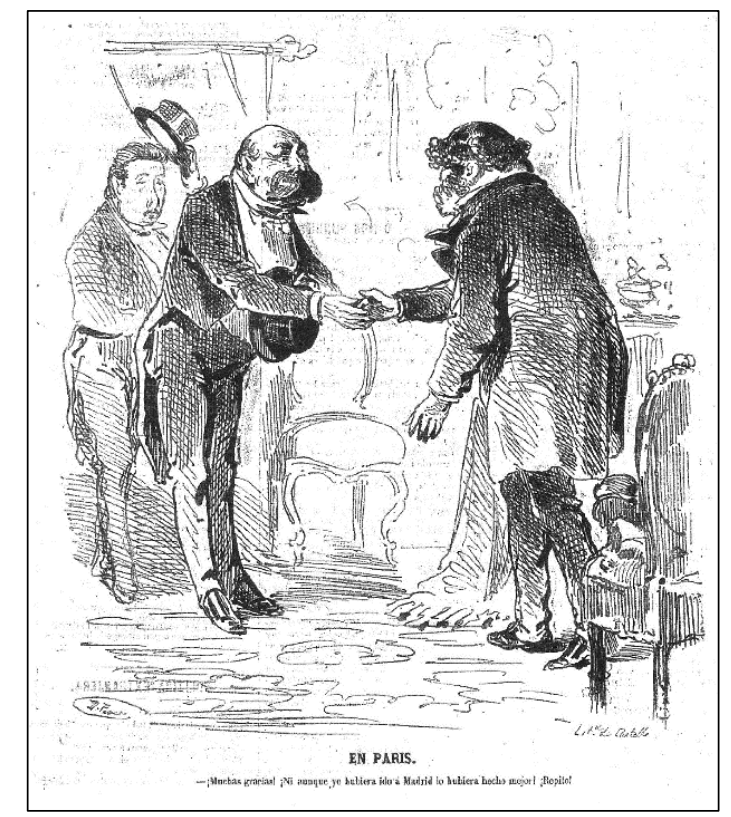

Fig. 4- Daniel Perea, En París, Gil Blas, 13 de diciembre de 1868

Una interpretación parecida hacen los caricaturistas cuando colocan al rey ante Napoleón III o ante Carlos María de Borbón y Austria-Este, pretendiente carlista al trono de España. Por lo que se refiere al emperador francés, la prensa satírica se hace eco inmediatamente del apoyo que presta a los reyes exiliados, aunque en vano, como esa caricatura de Daniel Perea en la que Napoleón III aparece reparando una corona y advierte a la reina: «Señora, se ha roto por un sitio que no tiene compostura» ${ }^{18}$. En ella, Francisco de Asís está representado de nuevo en segundo término como si fuera un lacayo (fig. 5$)^{19}$. 72.

${ }^{16}$ ¡La del humo!, Acuarela no 29 de la serie de "Los Borbones en Pelota”. Véase: Rubio, En torno,

${ }^{17}$ La caricatura, titula En París, es obra de Daniel Perea. Tiene el siguiente comentario, que alude irónicamente a lo que Olózaga dice a González Bravo: “Muchas gracias! ¡Ni aunque yo hubiera ido a Madrid lo hubiera hecho mejor! ¡Repito!”, Gil Blas, 13 de diciembre de 1868.

18 Gil Blas, 25 de octubre de 1868.

${ }^{19}$ La caracterización de Francisco de Asís es muy similar al dibujo que conserva la Biblioteca Nacional de España. DIB/18/1/8371 


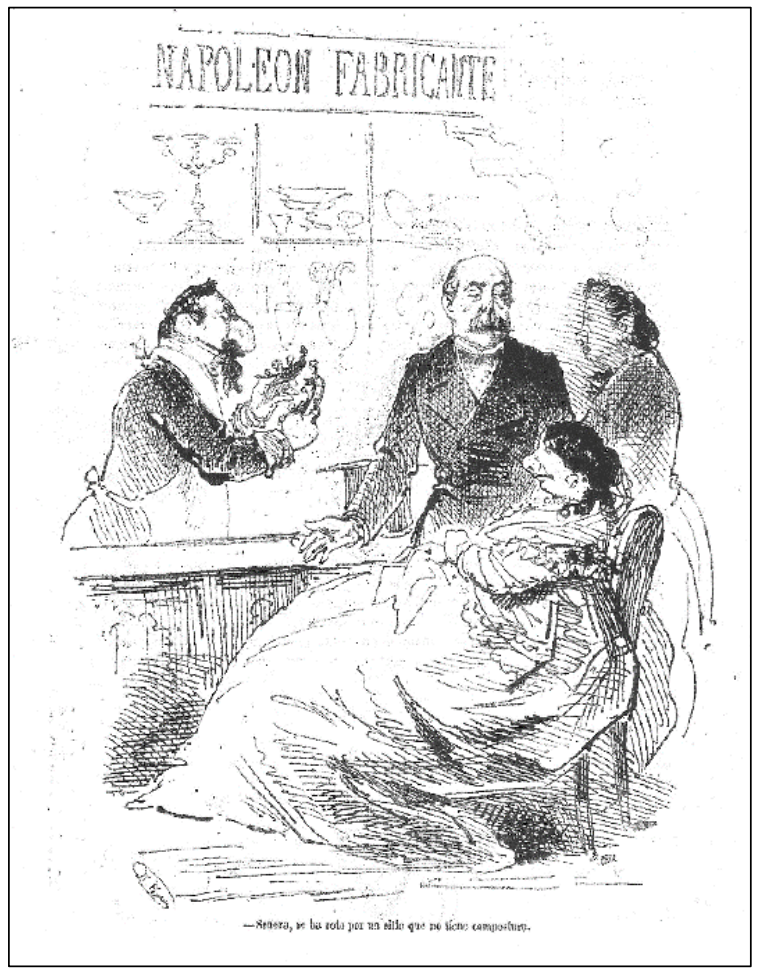

Fig. 5- Daniel Perea, Napoleón fabricante, Gil Blas, 25 de octubre de 1868.

De la atención que presta Napoleón III a los monarcas durante los primeros meses de su estancia en París hay bastantes noticias en los periódicos, lo que también explica, al menos en parte, su presencia en la caricatura. A principios del año 1869, cuando Francisco e Isabel todavía vivían en el Pavillon de Rohan, los visita, junto a la emperatriz y el príncipe imperial ${ }^{20}$. Unos días después, el landó de la emperatriz se cruza en los Campos Elíseos con el de la reina, a la que sigue su marido ${ }^{21}$. Los monarcas españoles asisten a misa en la capilla del Palacio de las Tullerías ${ }^{22}$. Particular solemnidad revistió una recepción que tuvo lugar, ya en el Palacio de Castilla, el 17 de abril de 1869, a la que no solo asistieron el emperador y la emperatriz, sino también el duque y la duquesa de Madrid -Carlos de Borbón y su esposa Margarita- que formaban parte de un selecto grupo de veinte invitados. Francisco de Asís los recibió al bajar del coche y, durante la cena, se colocó al lado de la emperatriz ${ }^{23}$. En compañía de su esposa y del príncipe Alfonso, Francisco de Asís realizó una excursión a finales de julio de 1869 a Saint-Cloud, desde donde los tres se dirigieron, en compañía del emperador y su esposa, a Versalles, volviendo a París por la noche ${ }^{24}$.

${ }^{20}$ Le Gaulois, 2 de enero de 1869. Una nueva visita tuvo lugar días después (La Presse, 12 de enero de 1860).

${ }^{21}$ Le Gaulois, 6 de enero de 1869.

${ }^{22}$ La Presse, 11 enero 1869.

${ }^{23}$ Le Figaro, 22 de abril de 1869. Más noticias del acontecimiento en Le Temps, 25 de abril de 1869. Lanza la hipótesis de que la reina Isabel abdicará en Carlos y este adoptará al príncipe Alfonso.

${ }^{24}$ Le Gaulois, 28 de julio de 1869. 
En la prensa española contraria a los Borbones se habla de la visita de «doña Isabel y doña Paquita» ${ }^{25}$. En la Navidad de aquel año, el emperador realizó otra visita al hotel Basiliewski, donde el príncipe Alfonso se reponía de la varicela ${ }^{26}$.

Por lo que se refiere a las reuniones entre los reyes y su pariente Carlos de Borbón, a las que asiste Francisco de Asís, son explicadas en la prensa de información general como negociaciones entre las dos ramas de la familia. Se da cuenta de distintos encuentros, como el ya mencionado, en alguno de los cuales se pone de manifiesto el descontento de Francisco de Asís ${ }^{27}$. En público se presentan como cordiales: así, durante las carreras de Longchamp, la reina Isabel y su marido se cruzaron con don Carlos y doña Margarita, a los que saludaron muy efusivamente, lo que dio pie a suponer un posible pacto $^{28}$. La caricatura ridiculiza estos eventuales acuerdos. Suele ironizarse sobre sus dificultades. En Jeremías, Francisco Ortego presenta al rey consorte como un bobalicón que hace pajaritas de papel para Sor Patrocinio (fig. 6), mientras su esposa y Carlos negocian ante la presencia de González Bravo ${ }^{29}$.

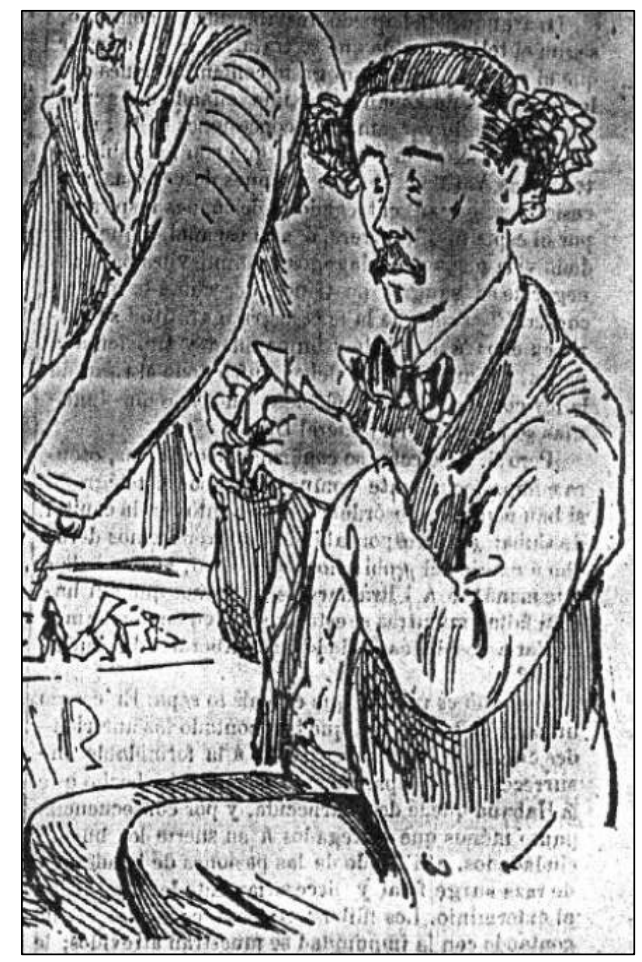

Fig. 6- Caricatura de Francisco de Asís (detalle), Jeremias, 31 de enero de 1869

\footnotetext{
${ }^{25}$ La Correspondencia de España, 156 de agosto de 1869.

${ }^{26}$ Le Figaro, 1 de enero de 1870.

${ }^{27}$ Le Figaro, 22 de enero de 1869.

${ }^{28}$ L'Univers, 17 de abril de 1869.

29 Jeremías, 31 de enero de 1869.
} 
Hay algunas más. En La Flaca, todos los miembros de la familia parecen enzarzados en una pelea, con el irónico título de «Una familia modelo»: Francisco de Asís es una figura secundaria que apenas alcanza a influir en la disputa ${ }^{30}$. Su presencia incluso se omite, como sucede en una caricatura de La Zurra, donde el exrey es sustituido por Carlos Marfori, representado como un dandi frívolo, mientras la reina cede a don Carlos un pedazo del pastel de España, que representa las provincias vascongadas ${ }^{31}$.

\section{EL PUEBLERINO COMO ANTÍTESIS DEL CIUDADANO}

La presencia del pueblo bajo con sentido despectivo, por ser inculto e influenciable, en relación con la manipulación a que se ve sometido por el poder en su propaganda, aparece tempranamente en la literatura política radical. Cuando Ayguals de Izco se burla de la entrada de la reina María Cristina en Madrid en 1844, hace referencia a una primera carroza, cuyas ninfas «quemaban olorosos perfumes para disipar sin duda el hedor tabernario que sus cuerpos exhalaban»; a esa sigue otra en la que se pavoneaban «seis ninfas de la misma estofa que las anteriores»; y concluye: «Parece que estas beldades habían sido elegidas entre lo más selecto de la aristocracia, esto es, entre las chuferas, naranjeras y bodegoneras más entusiastas del partido moderado» ${ }^{32}$.

En varias acuarelas de la serie «Los Borbones en pelota» aparecen cortesanos vestidos como tipos populares. Es el caso, por ejemplo, de Carlos Marfori ${ }^{33}$ y del propio rey Francisco de Asís ${ }^{34}$. En otro contexto, estas caracterizaciones tendrían un carácter amable: se explicarían en el marco de la costumbre de la aristocracia por retratarse con una indumentaria popular. Pero estas imágenes carecen de todo pintoresquismo. Muy al contrario, se trata de un disfraz que en la acuarela tiene claras intenciones denigratorias: el exrey es presentado como un paleto pueblerino, un ignorante que solo sabe tocar un instrumento musical para entretener.

El cambio de registro es tan importante que puede hacer olvidar esa tradición. Es necesario reconocerla para comprender que ha sido subvertida. El prestigio de la cultura urbana como lugar de la modernidad, donde el aldeano es una anomalía, un anacronismo, es un fenómeno que se detecta en las revistas ilustradas de la segunda

\footnotetext{
${ }^{30}$ La Flaca, 20 de febrero de 1870. En alguna ocasión la caricatura del rey Francisco de Asís ha sido confundida con la de su primo el exrey Francisco II de las Dos Sicilias, como en la ilustración publicada el 8 de enero de 1871. Véase: Dolores Troncoso. “Napoleón III y España," en La fuerza del bumor. Revistas satíricas del siglo XIX (Valladolid: Fundación Joaquín Díaz, 2013), https:// funjdiaz.net/imagenes/catalogos/catalogo_satiricas.pdf, consultado el 20 de mayo de 2019.

${ }^{31}$ José Chaves, Después de la Restauración, Tomad, querido primo, vuestra parte prometida, La Zurra, mayo 1869. Recogido por Jesús Carlos Méndez Paguillo, "Caricaturas y revistas satíricas en la Sevilla del siglo XIX", Revista Internacional de Historia de la Comunicación 9 (2017): 9. https://doi.org/10.12795/RiHC.2017.i09.01 consultado el 20 de mayo de 2019.

32 Wenceslao Ayguals De Izco, La marquesa de Bellaflor, o el niño de la inclusa (Madrid: Manuel Guijarro, 1869), II, 156.

33 Aparece con sombrero calañés en la acuarela 10(c) de la serie. BNE DIB 18/1/4838. Sobre las capacidades de seducción de Marfori, que tienen mucho que ver con su origen, véase: Le Siècle, 4 de octubre de 1868.

34 Por ejemplo, en las acuarelas núms 45 y 69 de la serei. BNE DIB 18/1/4900 y DIB 18/1/4910.
} 
mitad del siglo XIX de forma cada vez más insistente, pero rara vez alcanza el gran arte, como no sea para provocar patetismo, nunca para ridiculizar al tipo popular. En ese sentido, estas acuarelas evidencian un contexto de producción y de recepción eminentemente urbano y moderno, donde un mismo elemento tiene otro significado.

En un dibujo de Francisco Ortego publicado en Gil Blas que parodia un supuesto encuentro de los reyes con el Papa Pio IX, al que presentan a su hijo Alfonso, los monarcas también visten trajes populares (fig. 7). Se recurre a esta indumentaria con la intención de subrayar que no tienen ninguna fuerza que ofrecer ${ }^{35}$. Son personajes de pueblo que carecen de poder.

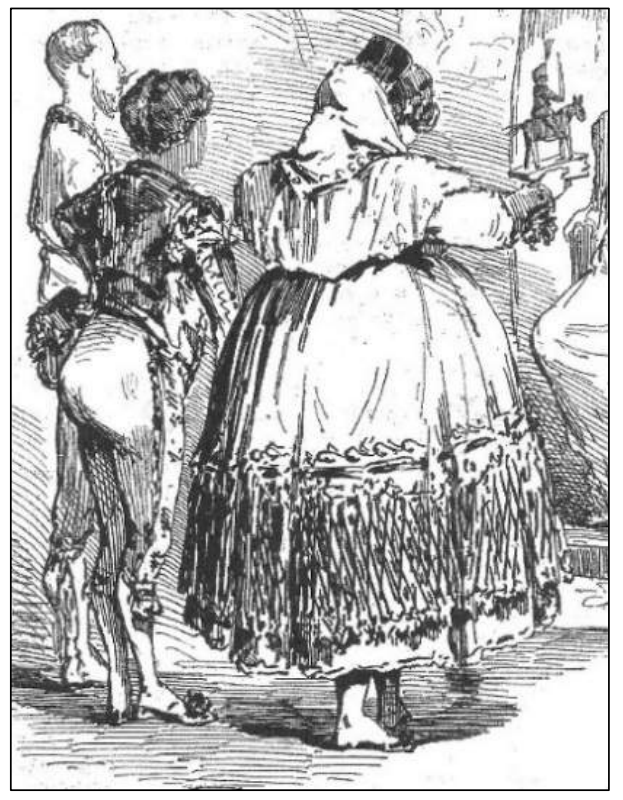

Fig. 7- Francisco Ortego, Contingente, Gil Blas, 1 de noviembre de 1868

\section{A UN REY NO DEBIERA IMPORTARLE EL DINERO}

El chantaje económico al que fue sometida la reina Isabel por su esposo para guardar silencio sobre sus infidelidades es anterior a la caída del régimen, pero la revolución no olvidó: «Ya sabes que yo he sido siempre amigo de tu honra. Te he servido de paraguas», le dice irónicamente el exrey a la exreina ${ }^{36}$. Sin duda eso contribuyó a formar una imagen de personaje mezquino y avaro, en las antípodas de la generosidad con la que suele asociarse la caballerosidad española. El exilio no solo no puso fin a ese imaginario, sino que lo intensificó. Los caricaturistas lo aprovecharon desde el primer momento. Daniel Perea, en una caricatura titulada En

\footnotetext{
${ }^{35} \mathrm{La}$ ilustración se titula Contingente y tiene el siguiente pie: "Os había ofrecido 30.000 hombres para defender el poder temporal. Os traigo el príncipe de Asturias, el único soldado que me queda" Gil Blas, 1 de noviembre de 1868. El 8 de marzo de 1870 tomó en Roma la Primera Comunión, ceremonia a la que no asistieron los reyes. Véase: Ángeles Lario, "Alfonso XII. El rey que quiso ser constitucional," Ayer 52 (2003): 17.

36 Gil Blas, 15 de mayo de 1870.
} 
París. El dinero español que se destina a la guerra civil sirve también para pagar los excesos de los señoritos $^{37}$, ridiculiza a Francisco de Asís, en quien acaban los dineros de la exreina (fig. 8).

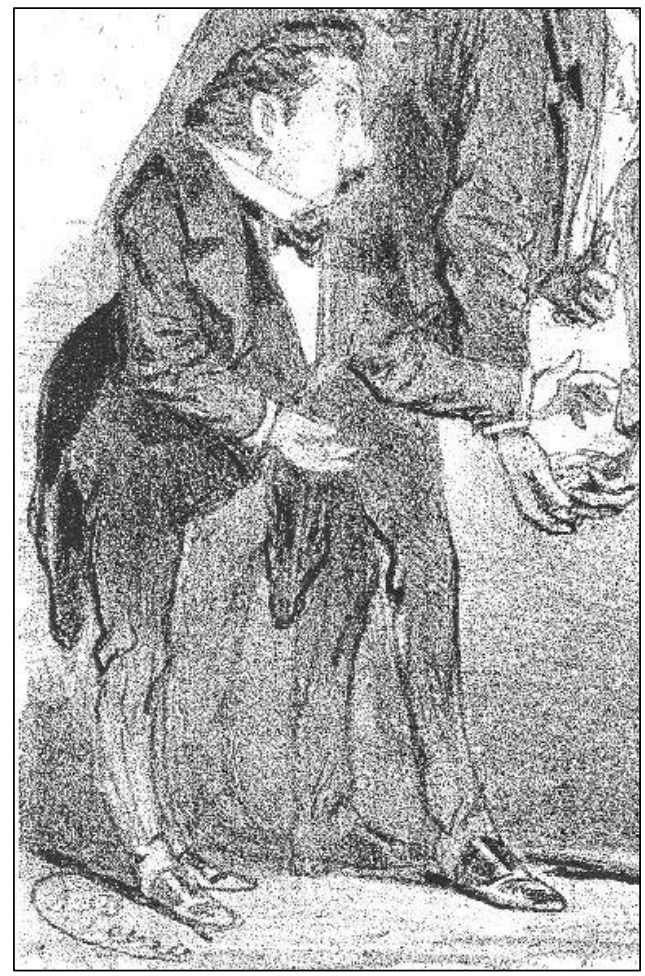

Fig. 8- Daniel Perea, En París (detalle), Gil Blas, 4 de febrero de 1869

$\mathrm{Al}$ respecto hay que subrayar que en la prensa francesa se ofrece, nada más llegar la pareja a París, alguna información sobre la vida social del exrey que pone de manifiesto sus preocupaciones económicas. Por ejemplo, la asistencia, en compañía del príncipe de Asturias, el conde de Ezpeleta, mayordomo de la reina, y otros personajes, a un convite con el barón de Rothschild, uno de los banqueros relacionados con su fortuna, al que no acude Isabel ${ }^{38}$. En España, cuando se empieza a hablar de la posible abdicación de la exreina, se relaciona con la independencia económica de su esposo, que, al fin, dejará de estar por debajo de ella ${ }^{39}$.

En ese sentido, el momento culminante de todo el debate económico sucede cuando se produce la separación matrimonial entre los antiguos reyes. El diario Le Figaro publica a principios de marzo de 1870 un poema del escritor Albert Millaud titulado «El pastor y la pastora», dedicado a Francisco de Asís y a su esposa, en relación con las reclamaciones económicas que el rey hace a su mujer. Anuncia que

37 Gil Blas, 4 de febrero de 1869.

38 La Presse, 20 de noviembre de 1868.

${ }^{39}$ La Esperanza, 1 de septiembre de 1869. 
va a iniciar un proceso que, de acuerdo con su contrato matrimonial, le concede la mitad de la corona y de los bienes:

-En Madrid se me agasajaba,

Era feliz siendo mudo,

La corte me hacía reverencias

Y Marfori me saludaba,

Siguiendo los dos, suertes contrarias

-Vos las preocupaciones, yo el recreo-

Vos no pensáis más que en los negocios

Yo no deseo más que los placeres

$[\ldots]$

Sin embargo, en París, yo he cambiado

En París levanto la voz.

Yo soy el señor Francisco de Asís,

Vos sois la señora de Francisco ${ }^{40}$.

De la cuestión se ocupa obviamente la prensa. El emperador aboga por un acuerdo amistoso ${ }^{41}$. Cuando se informa sobre el pacto, que coincide con una visita de Napoleón III y Eugenia de Montijo a la reina Isabel, a la que encuentra vestida de luto por los «dolores domésticos», añadidos a los del exilio, se indica que «este acto reglamenta definitivamente las condiciones financieras y el derecho respectivo de los esposos que viven desde ahora separados de cuerpos y bienes». Expresamente se insiste en que «una de las cláusulas formales es el compromiso de honor tomado por las dos partes de no vivir en común, cualquier cosa que pueda suceder». Sin embargo, se pone en cuestión la decisión de Francisco de Asís, que «había jurado emprender un viaje y dejar el hotel Basilewski; pero parece que no se ha decidido todavía a mantener su palabra» ${ }^{42}$. Se diría que la información tratara de desprestigiarlo, puesto que el monarca ya aparece domiciliado en el número 33 de la rue des Ecuries d'Artois el 14 de abril de $1870^{43}$.

En esa fecha Francisco de Asís procede a una cancelación de deuda, en beneficio de la exreina, consecuencia evidentemente de los acuerdos a los que había llegado con ella con anterioridad ${ }^{44}$. En otro documento fechado ese mismo día, el exrey concede «todos los poderes y autorizaciones necesarias a Su Majestad Isabel de Borbón, su esposa [...] al efecto de regir, gestionar y administrar tanto activa como pasivamente todos los bienes pasados, presentes y futuros». Eso implica que el exrey

40 Le Figaro, 2 de marzo de 1870.

${ }^{41}$ L'Univers, 15 de marzo de 1870

42 Le Figaro, 31 de marzo de 1870; Le Temps, 31 de marzo de 1870

43 Así consta en documentos notariales relativos a una cancelación de deuda (Véase nota siguiente). Algunos trabajos recogen que el rey vivió en un hotelito en la rue Saint Honoré, cerca, por tanto, de la reina (Vilar, "El primer exilio", 270). En realidad, no ocupó el número 91 de la rue Faubourg Saint Honoré (que no la rue Saint Honoré) hasta después de la Comuna.

${ }^{44}$ Se cita un acuerdo del 28 de febrero de 1870 con el gobernador del Banco de Francia, con el señor y la señora Rothschild, hermanos banqueros, residentes en París, rue Laffite, 21; y con el señor y la señora Dreyfus y compañía, con domicilio en la rue Grange Batelliere, 16. Toda deuda queda anulada definitivamente (Archives Nationales, Legajo MC/ET/II/1165). 
habrá de «recibir todas las rentas, arrendamientos, intereses, alquileres de rentas y otros beneficios vencidos y por vencer, y recibir los capitales que se le deban». Se hace explícita referencia a «los bienes muebles que le pertenezcan o le puedan pertenecer», incluido «el alquiler de apartamentos». Expresamente se declara adquiriente del Palacio Basiliewski y poseedor de distintas acciones ${ }^{45}$.

En estos documentos el exrey se muestra muy reivindicativo, con la clara intención de dejar resuelta su situación económica futura. De todos modos, la prensa se hace eco de una propuesta de reconciliación, en la que intervino el conde de Girgenti, Cayetano de Borbón-Dos Sicilias, esposo de la princesa Isabel, que contó con el apoyo del emperador y de la reina Cristina ${ }^{46}$.

La separación de los exreyes, que implicaba un acuerdo económico, estaba ligada a la abdicación de Isabel a favor de su hijo Alfonso, hecho que tuvo lugar, como se sabe, en el Palacio de Castilla de París el 25 de junio de 1870. El rey no asistió a aquella ceremonia: «había sido convocado, pero no creyó que tenía el deber de presentarse» ${ }^{47}$. Así pues, la opinión pública francesa (o, al menos, una parte de ella) estuvo informada de que la separación no fue tan amable como en ocasiones trataría de trasmitirse después. El testimonio del conde de Benalúa en sus memorias es explícito: «el Rey Don Francisco se oponía a ratos o exigía ciertas condiciones para autorizar con su asistencia a la abdicación ${ }^{48}$. En la prensa gala también se dio a conocer una carta de Francisco de Asís dirigida a su hija Isabel en la que explica los motivos por los que finalmente no acudió: «Hija mía, yo te digo que, si España merece tener por rey a uno de mis hijos, tu serías reina, o nadie será rey en mi familia. Tu verás que grito yo lanzaría en el último momento. Después de todo, ¿qué tengo que perder??»

Las caricaturas publicadas en estos meses traducen este conflicto. Con el título El desafío en el Palacio Basiliski, denominación modificada para acercarla al término basilisco, Francisco Ortego presenta una imagen débil del exrey, dominado por Isabel, que le humilla (fig. 9). Es el momento en el que el periódico informa de que los cónyuges vivirán separados. Con ironía, el cronista se compadece de que don Francisco de Borbón se vea en la necesidad y tenga que vivir con seis mil duros al mes: «¿No es triste haber aceptado el empleo honorario de esposo oficial de una reina, y padre ad honorem de varios príncipes, y resultar ahora marido de una señora particular, con los inconvenientes de todos los maridos y sin ninguna de sus ventajas?» ${ }^{50}$.

45 Archives Nationales, Legajo MC/ET/II/1165.

${ }^{46}$ Le Gaulois, 25 de mayo de 1870 ; Le Temps, 25 de mayo de 1870.

${ }^{47}$ L'Univers, 28 de junio de 1870.

${ }^{48}$ Julio Quesada Cañaveral y Piédrola, Memorias del conde de Benalúa (Madrid: Blass S.A. Imprenta, 1924), I, 51.

${ }^{49}$ Le Figaro, 7 de julio de 1870.

${ }^{50}$ Gil Blas, 17 de marzo de 1870. 


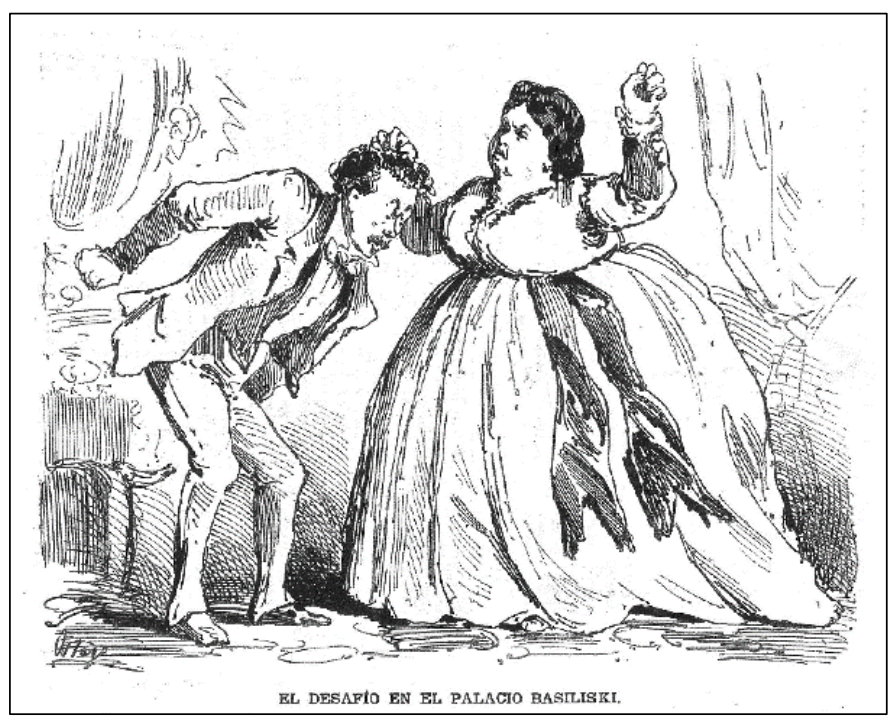

Fig. 9- Francisco Ortego, El desafío del palacio Basiliski, Gil Blas, 17 de marzo de 1870

El mismo dibujante caracteriza al exrey como el espectro de Banquo, el personaje de Shakespeare que se aparece a Macbeth después de haberle asesinado y al que solo él puede ver (fig. 10). La reina como Lady Macbeth pregunta: «¿Qué quieres, oh espectro solo visible para mí?», a lo que Banquo responde: «iMas sueldo, o cantaré claro! $\rangle^{51}$.

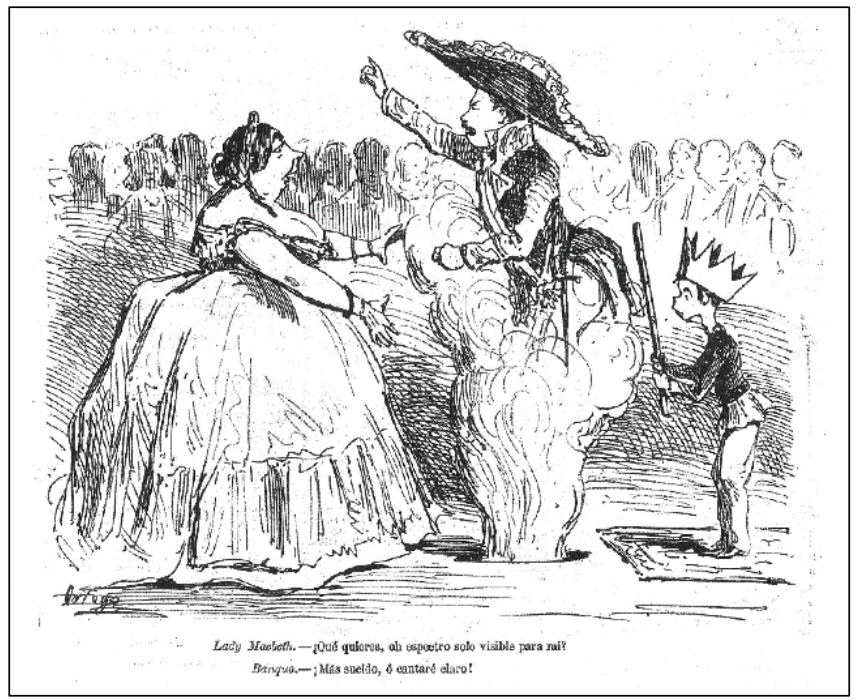

Fig. 10- Francisco Ortego, Parodia de Macbeth, Gil Blas, 3 de julio de 1870

51 Gil Blas, 3 de julio de 1870. 


\section{UN REY NO ELIGE DIVERSIONES FRÍVOLAS}

Lejos del sufrimiento al que la prensa francesa alude en algunas ocasiones cuando los exreyes atraviesan la frontera o cuando se separan- lo cierto es que la vida de Francisco y de Isabel en el París de los últimos años del Segundo Imperio está llena de diversiones, algunas muy frívolas, como esa misma prensa también se encarga de hacer ver. No existió nunca, desde luego, la pretensión de asumir el exilio parisino como un purgatorio: cuando todavía residían en el Pavillon de Rohan se habla de un tal señor Straus, jefe de orquesta de los bailes de la Corte, que había sido invitado a dirigir los que pronto se celebraran en el Palacio de Castilla ${ }^{52}$. En España, el periódico antiisabelino La Regeneración también se hace eco de este tipo de noticias, buscando motivos para el desprestigio: «D. Francisco de Asís se pasa una vida muy agradable, a la cual ha tomado mucho gusto, y dice a cuantos le quieren oír que aquí es amo, mientras en Madrid no era más que consortes ${ }^{53}$.

En París se informa de las preferencias del exrey por las diversiones mundanas. A finales del mes de agosto de 1869 se dice que «el rey Francisco ha venido a toda prisa desde Trouville para ver una pieza teatral. Se ha divertido mucho a juzgar por las muestras de aprobación», y, «al salir del teatro, don Francisco ha ido como un simple mortal a tomar un bock a la brasserie Herser». El cronista dice que ha firmado un autógrafo al camarero con las palabras siguientes: «Yo hago poco caso de la adulación y todavía menos de la chismografía». Aunque recomienda «hacerle poco caso en todo», constituye un testimonio de la actitud de desdén y falta de prejuicios del monarca, que, por cierto, volvió a Trouville después de su escapada ${ }^{54}$.

Se da noticia, incluso, de su asistencia a espectáculos concretos, por lo general de carácter ligero. Así, en septiembre de 1869, Francisco de Asís acude, en compañía de su esposa, a la representación de La Chatte Blanche, en el teatro de la Gaité. Cuando llegaron, el portero suspendió la entrada del público y los asistentes tuvieron que esperar a que entraran los reyes ${ }^{55}$. De aquella opereta, con texto de Théodore e Hippolyte Cogniard, inspirada en un cuento de Marie-Catherine d'Aulnoy publicado en 1697 y adaptado con mucho éxito en el siglo XIX, se conserva distinto material gráfico impreso en el año 1869, que da idea del tipo de espectáculo: en una litografía titulada La gata blanca en el teatro de la Gaité, de A. Belloguet, se aprecia el carácter carnavalesco de la función en su conjunto ${ }^{56}$, que ha de relacionarse con la afición de las clases altas por disfrazarse. Por otra parte, es muy significativa la caricaturización de los actores, como se aprecia en un grabado de Félix Regamey, según dibujo de

52 Le Gaulois, 2 de enero de 1869.

${ }^{53}$ La Regeneración, 13 de julio de 1869.

${ }^{54}$ Le Gaulois, 22 de agosto de 1869.

${ }^{55}$ Le Figaro, 10 de septiembre de 1869. Se había estrenado el 16 de agosto.

56 Bibliothèque nationale de France, département Bibliothèque-musée de l'opéra, http://catalogue.bnf.fr/ark:/12148/cb413368906 
Jalap, que representa a la actriz Thérésa ${ }^{57}$; o una carte de visite de Nadar, en la que aparecen los actores caricaturizados ${ }^{58}$.

La propia prensa española trasmite la idea de que París, donde viven los reyes, es un lugar de diversión, lo que sutilmente se asocia con ellos. Así, se hace referencia a una zarzuela bufa que se representa en el teatro de la Zarzuela de Madrid titulada La Vida Parisiense. Gil Blas caricaturiza los personajes, entre los que aparece «el almirante Walter con $i S u$ casaca rota por detrás, por detrás. $\rangle^{59}$, que podría aludir al rey Francisco y a los rumores sobre su sexualidad: la referencia a la puerta de atrás para referirse a prácticas sodomíticas es habitual ${ }^{60}$.

Ante esta nueva forma de vida, la prensa española asegura que don Francisco no quiere volver a España de ninguna manera ${ }^{61}$. En Francia, mientras tanto, se sigue informando sobre su asistencia a espectáculos frívolos. En diciembre de 1869 acudió, en compañía del duque de Baviera -su cuñado Adalberto-, a una representación en el Théatre des Bouffes Parisiens, donde se divirtió con Madame Céline Chaumont. En la misma noticia se indica que iría al Varietés un día de esa semana ${ }^{62}$. Los carteles anunciadores de aquellas diversiones dan idea del tono de estas.

También se constata su presencia en los salones, como el de la princesa de la Témoille, baronesa de Wykerslooth, que, «más brillante que nunca», se celebró en su hotel de la avenue Montaigne el martes 15 de febrero de 1870. Un cronista asegura haber visto allí a Francisco de Asís, entre otras personas distinguidas, que animaron la «velada encantadora en un cuadro mágico»; destaca el «gran éxito de una encantadora cantante, la señorita Rubini» y la presencia de «la graciosa señora de Klindworth [que] ha tocado el piano con el talento de una gran artista» ${ }^{63}$.

Todo ello parece ha de ponerse en relación con la acuarela número 22 de la serie «Los Borbones en pelota» titulada El Carnaval en París, con esta explicación: «Gran quadrille. / —A tanta tribulación / Como nos dieron y dan, / La mejor contestación / Será baylar un cancán $»^{64}$. Mientras la vida social de la exreina en París era bastante reducida, se diría que la de Francisco responde a una realidad mucho más social.

\footnotetext{
57 Bibliothèque nationale de France, département Musique $\frac{\text { http://catalogue.bnf.fr/ark:/12148/cb39626838d }}{58 \quad \text { Bibliothèque nationale de France, département Arts du spectacle }}$ http://catalogue.bnf.fr/ark:/12148/cb39513350s

${ }^{59}$ Gil Blas, 29 de julio de 1869.

${ }^{60}$ Emmanuel Fureix, "'La porte de derrière'. Sodomie et incrimination politique : des caricatures contre Cambacérès (1814-1815)," Annales historiques de la Révolution française 362 (2010): 109-130. https://doi.org/10.4000/ahrf.11704 consultado el 20 de mayo de 2019.

${ }^{61}$ Elpensamiento español, 17 de noviembre de 1869.

${ }^{62}$ Le Gaulois, 15 de diciembre de 1869.

${ }^{63}$ Le Figaro, 18 de febrero de 1870.

${ }^{64}$ Madrid, Biblioteca Nacional de España. Sign. DIB 18/1/4890. También se ha localizado una litografía que remite a esa misma escena: Rubio Jiménez-Urbina, Imagen y política, 112.
} 


\section{UN REY HA DE SER AUTÉNTICO PADRE}

La caricaturización del rey como un cornudo constituye un lugar común de su visualización deslegitimadora ${ }^{65}$. Las infidelidades de su esposa le desacreditan como hombre. El asunto también encuentra eco en Francia, donde se cuenta la anécdota de que en el convento de Calatrava de Madrid había un cuadro de la Virgen con el niño, junto a una pintura del rey vestido con el hábito de aquella orden militar. Un guasón que quiso divertirse adornó la cabeza de este retrato con los cuernos de Moisés cuando bajó del Sinaí, aunque fueron borrados enseguida ${ }^{66}$. La ausencia del exrey Francisco de Asís de la ceremonia de abdicación de Isabel II en su hijo es interpretada como un cuestionamiento de su paternidad ${ }^{67}$.

Esta circunstancia contrasta con una cierta insistencia de la prensa francesa en presentar a Francisco de Asís como especialmente preocupado por la educación de Alfonso. Tras las vacaciones del verano de 1869 en las costas del Canal, ambos fueron vistos juntos paseando por París, según anota un cronista: «Ya no hay más baños de mar. Ayer [...] me encontré [...] a don Francisco de Asís con su sombrilla, y al príncipe de Asturias con su cometas ${ }^{68}$. La proximidad entre Francisco y Alfonso se intensifica en la prensa de los años posteriores, en ocasiones con recuerdos de aquellos años, como el hecho de haberle acompañado, junto a su madre, al lugar donde realizó los primeros estudios en París ${ }^{69}$.

En España, sin embargo, la paternidad de Francisco de Asís se presenta en la caricatura como un asunto de conveniencia política, al que se hace referencia nuevamente, de forma ridícula, cuando a finales de 1874 se vislumbra la posibilidad de una restauración monárquica. Una viñeta presenta al exrey con gesto de desagrado, uniendo sus manos con las de la reina, mientras el joven príncipe abraza a ambos. Al pie se indica que "Güell y Renté querría verlo así" (fig. 11) ${ }^{70}$. Hace referencia a las pretensiones de José Güell y Renté, cuñado de Francisco de Asís, en tanto que esposo de su hermana Josefina Fernanda. La prensa española se había hecho eco poco antes de que "el exrey consorte ha reanudado las buenas relaciones con su esposa" y con otros miembros de su camarilla, entre los que se cita a su cuñado, y se disponía a apoyar la causa de alfonsina. Güell y Renté envió incluso una carta a la prensa explicando su posición ${ }^{71}$.

${ }^{65}$ No solo varias acuarelas de la serie "Los Borbones en pelota" presentan al rey con una gran cornamenta, sino también otro tipo de imágenes, como se recoge en la bibliografía precedente.

66 Dictionnaire Larousse, 1872, 776.

${ }^{67}$ Luis Rivera, “¿Por qué no asistió el papá?”, Gil Blas, 3 de julio de 1870.

${ }^{68}$ Le Rappel, 30 de agosto de 1869.

${ }^{69}$ Robert de Bonnières, Mémoires d'aujourd'bui, 3e série (París: Paul Ollendorf, 1888), 214.

70 L'Esquella de la Torratxa, 22 de noviembre de 1874.

${ }^{71}$ El Imparcial, 2 de septiembre de 1874. 


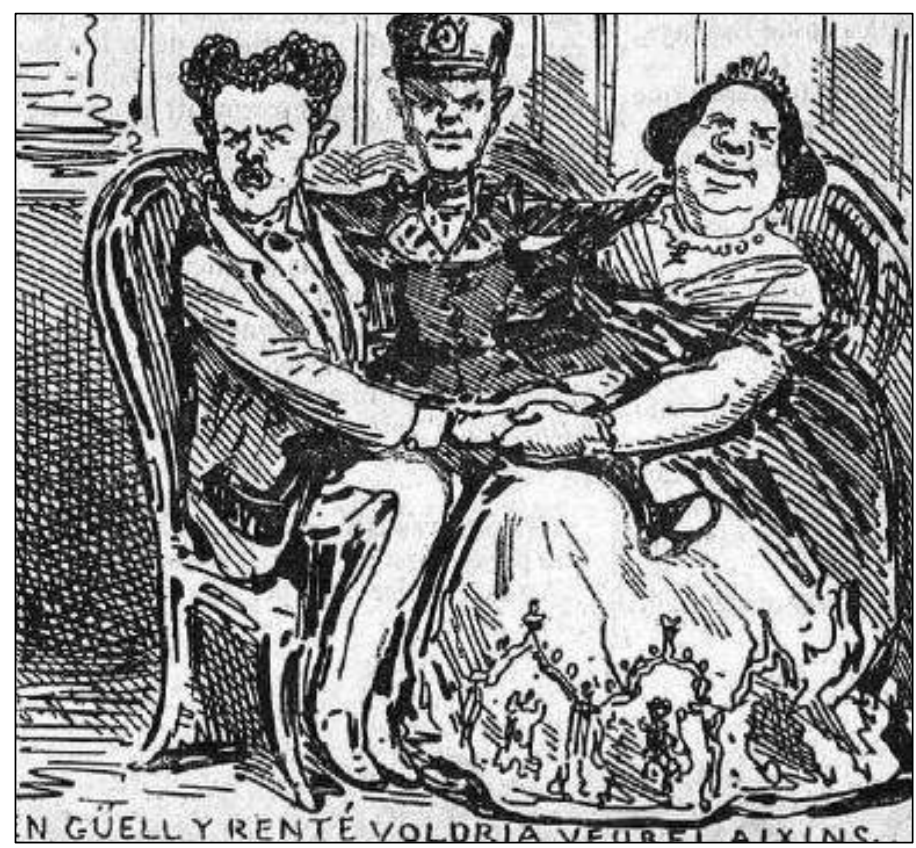

Fig. 11- Güelly Renté querría verle así, L’Esquella de la Torratxa, 22 de noviembre de 1874.

La puesta en duda de su paternidad es uno de los recursos utilizados por los dibujantes para desacreditarlo como hombre y, en última instancia, como rey. Los cuernos, indicativo visual de las infidelidades de su esposa, aparecen en la caricatura impresa. Así, en un panfleto catalán titulado Diálogo entre Xacó, Isabel y Mossen Clarine $^{72}$, ilustrado con una xilografía en la que el padre Claret y la reina que bailan con frenesí, aparece Francisco de Asís, sorprendido de aquella lasciva exhibición, con los cabellos peinados de tal modo que semejan cuernos (fig. 12). Esta imagen guarda relación con la acuarela $n^{\circ} 22$ de Los Borbones en pelota, titulada «El carnaval de París», prueba de cómo «el dinamismo semántico confiere generalmente una potencialidad mutante bastante pasmosa a las imágenes del 'contrapoder'. Por su propia vitalidad, llegan a escapar de las manos de sus propios creadores» ${ }^{73}$.

${ }^{72}$ Barcelona, Arxiu Municipal, Gravat no 550. Está en relación con la acuarela $n^{\circ} 22$ de la serie «Los Borbones en pelota».

${ }^{73}$ Jaime Cuadriello. "Iconografía del 'contrapoder': resistencia, transgresión y conflicto,” en La imagen política. XXV Coloquio Internacional de Historia del Arte Francisco de la Maza', ed. Cuauhtémoc Medina (México: UNAM-Instituto de Investigaciones Estéticas, 2006), 21-22. 


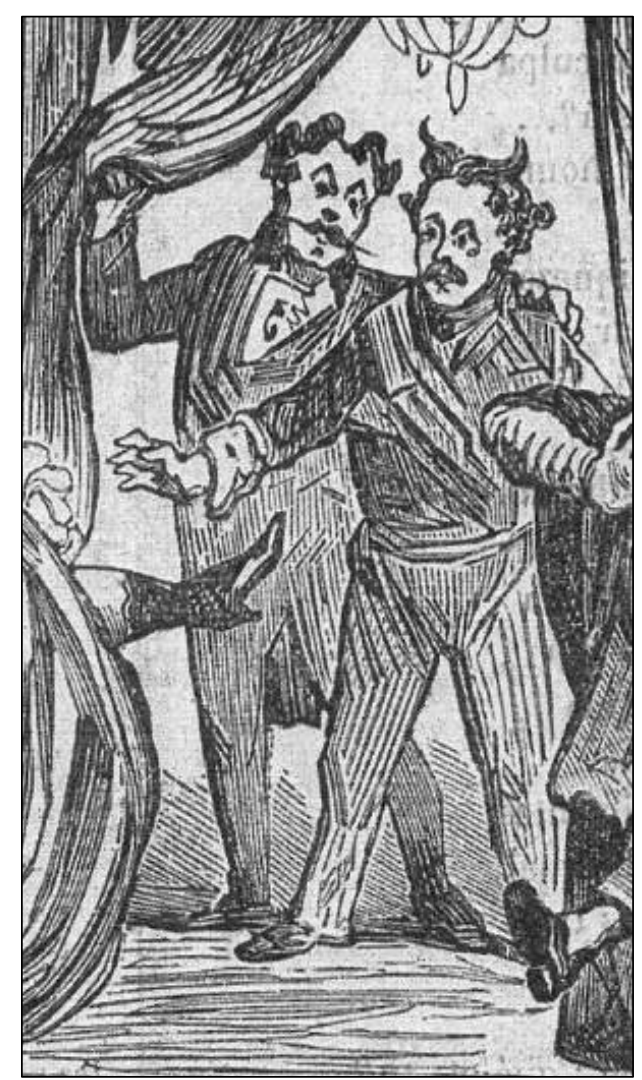

Fig. 12- Diálogo entre Xacó, Isabel y Mossen Clarinet (detalle), ca. 1870, Barcelona, Arxiu Municipal

El exrey Francisco es representado con cuernos, también como una modificación de sus cabellos, en una caricatura publicada en la revista barcelonesa El ojo (fig. 13). Titulada Gran corrida de Velocipedo, los antiguos protagonistas de la corte isabelina -en el momento de la publicación de la viñeta exiliados en Franciaobservan, junto a Napoleón III y Carlos de Borbón, el proceso revolucionario, como si se tratara de un gran espectáculo ${ }^{74}$.

${ }^{74}$ El Ojo, 2 de junio de 1869. 


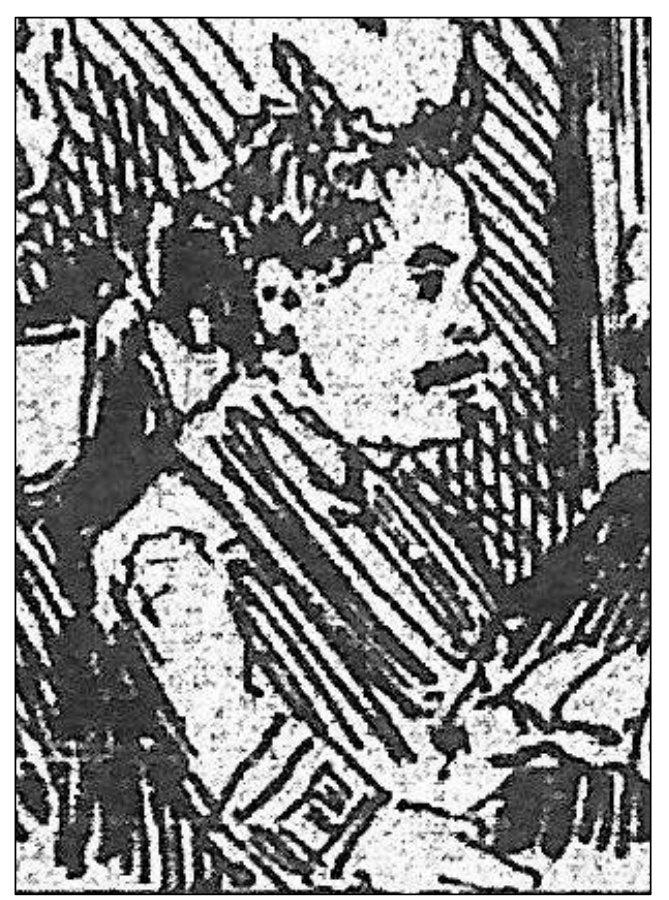

Fig. 13- Gran corrida de velocipedo (detalle), El Ojo, 2 de junio de 1869

\section{UN REY HA DE SER DISCRETO CON SUS AMISTADES FEMENINAS}

Muchos hombres públicos del siglo XIX tuvieron amistades íntimas femeninas que no afectaron, en general, a su prestigio como caballeros. Se diría que la clave para hacer tolerable esta situación, cada vez más cuestionada por el puritanismo imperante, en cualquier caso, implicaba dos condiciones: por un lado, guardar una cierta discreción, de manera que el orden social correcto no apareciera cuestionado; y, de otro, que estas mujeres resultasen fascinantes y mundanas, es decir, irresistibles a la mirada masculina. La ausencia de ambas condiciones contribuyó a deslegitimar la figura del exrey.

La proximidad a Sor Patrocinio, no solo por su estado de religiosa sino por su condición de mujer, es determinante en ese sentido. En la prensa española se relaciona la ausencia de Francisco de Asís del acto de abdicación de la reina con una visita a la monja de las llagas, sobre las cuales versó supuestamente la conversación ${ }^{75}$. Se da la coincidencia de que, en efecto, aquel verano el rey visitó a Sor Patrocinio en el convento de Montmorency, en el que se había refugiado. La prensa se hace eco del afecto que la monja profesa al monarca: «cuando el exrey Francisco de Asís va a visitar a la hermana Patrocinio, el convento se llena de alegría». El cronista evoca explícitamente un encuentro entre las monjas, «vis a vis con su soberano», forma de relación que juzga contraria «a los aspectos modernos de nuestras costumbres

${ }^{75}$ La Flaca, 10 de julio de 1870. 
democráticas». Todas las religiosas que le recuerdan se muestran especialmente afectuosas:

Las hermanas cargadas de cuidados domésticos en el convento caen de rodillas y besan la mano del rey.

El rey, con un humor dulce, de ideas liberales y fácil de abordar, se presta con una gracia emocionada.

Las otras hermanas no hacen más que una inclinación ligera, pero le besan también la mano.

La hermana Patrocinio se la aprieta también como viejo amigo.

La visita coincidió con una estancia de Francisco de Asís en el cercano establecimiento termal de Enghien-les-Bains, como consecuencia de una afección en las cuerdas vocales: «Es en el momento de abandonar el establecimiento cuando viene temprano por la mañana a visitar algunas veces a la hermana Patrocinio». Allí «se interesa por la suerte de las hermanas [...], acude en su ayuda, pero con donativos discretos. La norma del convento le obliga a una cierta reserva. El voto de pobreza y la regla de convento limitan las generosidades reales» ${ }^{76}$.

Una vez más se aprecia la conexión entre una de las acuarelas de la serie de «Los Borbones en pelota»y los detalles vertidos en esta información, naturalmente tergiversados $^{77}$. A propósito de la posibilidad de que Francisco de Asís retornase a España como particular, se le advierte, como para quitarle la idea, de que «apenas quedan ya conventos de monjas» ${ }^{78}$.

\section{UN REY ES UN HOMBRE VIRIL}

La virilidad constituye un rasgo indispensable en cualquier varón. Más grave es que falte en un monarca. Se alude a su carencia como un procedimiento deslegitimador, no solo del individuo como tal sino, sobre todo, de su capacidad para dirigir los asuntos del estado. La sexualidad desviada, respecto a un modelo social impuesto, empezó a ser utilizada como arma política, cada vez con más frecuencia, como consecuencia de la asociación entre moralidad privada y virtud pública que se impuso a raíz de la Ilustración.

La caricatura política fue particularmente cruel con algunos personajes, como el marqués de Villette ${ }^{79}$ o Jean-Jacques Régis de Cambacères, segundo cónsul del imperio ${ }^{80}$. En el caso de Francisco de Asís, arrastrado por comentarios sobre su sexualidad desde su matrimonio con su prima Isabel ${ }^{81}$, la cuestión explotó en la imagen a raíz de su exilio. Para sugerir la falta de virilidad, el caricaturista se apoya en

76 "Une visite à la soeur Patrocinio à Montmorency", Le Figaro, 28 de julio de 1869.

${ }_{77}$ Acuarela no 87. Madrid, Biblioteca Nacional. DIB 18/1/4872.

78 Gil Blas, 3 de noviembre de 1870.

${ }^{79}$ Jeffrey Merrick. "The Marquis de Villette and Mademoiselle de Rancourt: Representations of Male and Female Sexual Deviance in Late Eighteenth-century France," en Homosexuality in Modern France, ed. Jeffrey Merrick y Bryant T. Ragan (Oxford: Oxford University Press, 1996), 30-53.

${ }^{80}$ Fureix, La Porte, 109-130.

${ }^{81}$ Isabel Burdiel, Isabel II. Una biografía (Madrid: Taurus, 2010), 159-181. 
su propia apariencia, subrayando ciertos rasgos físicos. Específicamente se realzan sus nalgas redondeadas, un elemento distintivo que también se da en otros personajes $^{82}$. Así le dibuja Francisco Ortego en una caricatura titulada Ayer, Últimas horas de reinado (fig. 14). La revista donde se publica incluye un comentario sobre su afeminamiento:

El buen Francisco lloró como una Patrocinio.

Y prorrumpía entre sollozos: ‘¿Dónde está esa gente que me servía y me adulaba antes, y ahora, joh! Ahora probablemente me maltratarán por detrás, puesto que ni aun sus diatribas ni sus maldiciones logro hacer llegar a mis oídos ${ }^{83}$

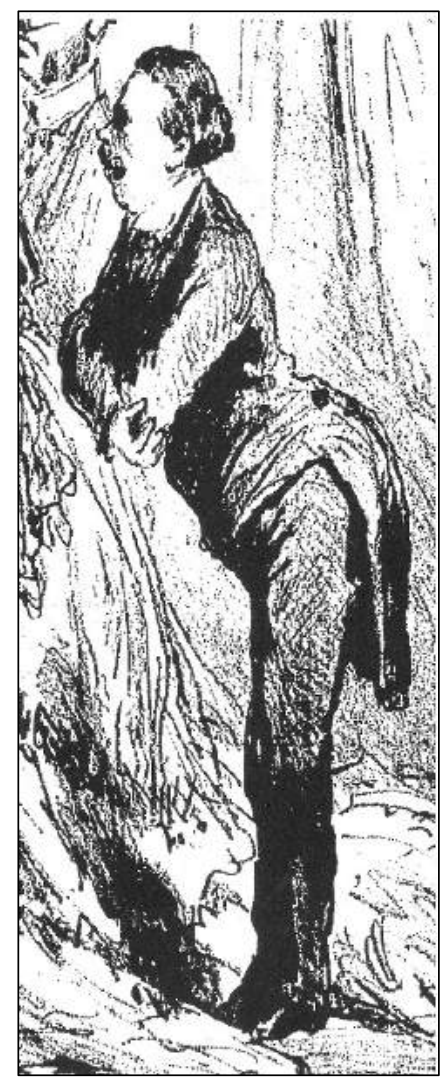

Fig. 14- Ayer. Últimas horas de reinado (detalle), El Siglo Ilustrado, 4 de octubre de 1868

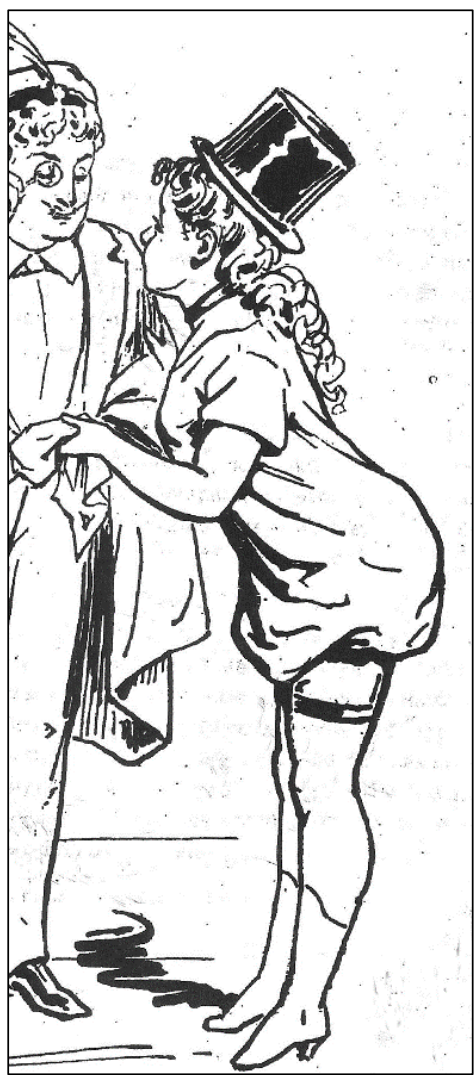

Fig. 15- Ilustración de L'Éclypse (detalle), 8 de julio de 1877

82 Fureix hace explícitamente alusión a las «fesses rebondies» de Cambacères (Fureix, La porte, 111)

${ }^{83}$ El Siglo Ilustrado, 4 de octubre de 1868, 575. Véase también: Rubio, En torno, 71. 
Esta disposición coincide con el perfil que suelen adoptar las muchachas jóvenes en la caricatura francesa cuando se ironiza sobre su capacidad de seducción (fig. 15) ${ }^{84}$. En general, la exageración del trasero en un hombre tiene como objetivo ponerle en ridículo, acusándole de afeminamiento: así, un oficial alemán es caricaturizado como un pavo con plumas en el culo, tras la victoria sobre Napoleón III $^{85}$. La expresión francesa «avoir une plume dans le culi, hace referencia a las bailarinas de cabaret y a modales poco viriles.

Otras veces se visualiza la inversión. Es frecuente en la caricatura política que los hombres adopten una apariencia femenina como forma de burla, sin que eso implique una alteración de los roles sexuales ${ }^{86}$. Esta presentación invertida de la condición masculina hay que relacionarla con una larga tradición relacionada con el recurso del mundo al revés, fenómeno que sobrevive en el último cuarto del siglo XIX, como en la aleluya Le monde à l'envers, de $1878^{87}$. En algunos casos, sin embargo, como el citado de Cambacères, la indumentaria femenina alude también a una inversión sexual ${ }^{88}$. Una de las caricaturas de la serie «Los Borbones en pelota» coloca la figura de Francisco de Asís de forma invertida, como si fuera un acróbata en la cuerda floja, lo que se ha interpretado como una alusión explícita a su sospechada homosexualidad ${ }^{89}$.

La feminización del exrey Francisco de Asís en la prensa española es recurrente desde el mismo momento de su exilio. Por ejemplo, Gil Blas ofrece como regalo «una fotografía del heroico y esforzado paladín del trono caído D. Francisco de Asís Borbón y Borbon(a) Paquita» $»^{90}$.

\section{CONCLUSIÓN}

El análisis que se presenta permite categorizar determinados modos de ver al rey Francisco en cuanto personaje público, sin duda con la intención de desacreditarlo. En este proceso de deslegitimación juega un papel fundamental el cuestionamiento de los comportamientos propios de un hombre, indispensables para ocupar el trono. Si antes de 1868 la antigua majestad regia había sido sustituida por las reglas de la caballerosidad burguesa como elemento de propaganda, ahora es su carencia la que justifica su exclusión del orden político.

${ }^{84}$ Véase, por ejemplo, L’Éclypse, 8 de julio de 1877.

${ }^{85}$ L'Éclypse, 21 de agosto de 1870.

86 Isabelle Mornat, "Masculino/femenino: estereotipos e inversiones en la caricatura española (siglo XIX)", 2014. < hal-01346438> https://hal.archives-ouvertes.fr/hal-01346438 consultado el 20 de mayo de 2019.

${ }^{87}$ Bibliothèque nationale de France, département Estampes et photographie, FOL-LI-59 (9) http://catalogue.bnf.fr/ark:/12148/cb413883476

88 Es el caso del aguafuerte titulado Ma tante Urulette. Bibliothèque nationale de France, département Estampes et Photographie, RESERVE QB-370 (71)-FT 4, http://catalogue.bnf.fr/ark:/12148/cb41515559x.

${ }^{89}$ Acuarela $n^{\circ}$ 36. Madrid, Biblioteca Nacional DIB 18/1/4896

${ }^{90}$ Gil Blas, 1 de octubre de 1868. 
El hecho de que la caricatura política sea una subcultura estética, construida al margen de los códigos empleados por los géneros artísticos en un ámbito culto, no resta potencial comunicativo a estas imágenes, sino al contrario: la existencia, como se ha demostrado, de un paralelismo entre la vida cotidiana del exrey en el exilio y la configuración de su imagen pública en España ha de entenderse como una voluntad de contar una historia verídica, aunque deformada, en la que salen a la luz todos los temores de una sociedad hacia determinados defectos de quienes, siendo hombres y obligados a parecerlo, ejercen el poder. Es evidente que la crítica contra el rey aprovecha la denigración de la homosexualidad en ámbitos burgueses, al igual que la misoginia había servido para censurar a María Luisa de Parma ${ }^{91}$ o a Isabel $\mathrm{II}^{92}$. Si el discurso feminista ha obligado a pensar «qué cosa debían ser las mujeres», ante la anomalía de una mujer en el trono, no es menos necesaria la reflexión sobre otro conflicto indisociable de ese: qué cosa debe ser un hombre que es rey, pero carece del poder que debiera corresponderle. Se ha subrayado la importancia del papel familiar como elemento legitimador: por ejemplo, las cartas de afecto hacia a su mujer o la preocupación por sus hijos, de las que se hace eco la prensa como instrumento de propaganda, a pesar de que constituyen una suerte de emasculación ${ }^{93}$. Precisamente contra la ausencia de responsabilidad en la nueva posición que ha de ocupar como marido y como padre, según el patrón familiar burgués, de la que la Familia Real es referente, carga la caricatura: Francisco de Asís no es un modelo de esposo ni de padre porque no es un modelo de hombre. Por lo tanto, carece de legitimidad para ocupar el puesto de rey.

${ }^{91}$ Antonio Calvo Maturana, "Eva y la pérdida del paraíso imperial. Alegorías misóginas de María Luisa de Parma en el siglo XIX," Reales Sitios 67 (2006): 68-77.

92 Burdiel, Los Borbones, 69.

93 Burdiel, Los Borbones, 25. 


\section{REFERENCIAS BIBLIOGRÁFICAS}

Alcalá Galán, Mercedes. "Stupeur et tremblements. Estática de lo obsceno en 'Los Borbones en pelota'," en Venus Veneranda II. Literatura erotica y modernidad en España, ed. Adrienne L. Martin y José Ignacio Díez (Madrid: Universidad Complutense, 2008), 53-78.

Ayguals de Izco, Wenceslao, La marquesa de Bellaflor, o el niño de la inclusa (Madrid: Manuel Guijarro, 1869).

Baedeker, Karl, Paris. Guide pratique du voyageur (París, 1860).

Bonnières, Robert de, Memoires d'aujourd'hui (París: Paul Ollendorf, 1888).

Burdiel, Isabel (edición y estudio introductorio), SEM. Los Borbones en pelota (Zaragoza: Institución Fernando el Católico, 2012).

Burdiel, Isabel. "Historia de una desactivación: el exilio parisino de Isabel II (18681904)," en El exilio español durante los siglos XIX y XX, ed. Fernando Martínez, Jordi Canal y Encarnación Lemus (Madrid: Sociedad Estatal de Conmemoraciones Culturales-Marcial Pons, 2010), 55-84.

Burdiel, Isabel, Isabel II. Una biografía (Madrid: Taurus, 2010).

Cabra Loredo, María Dolores. "Sem y el burdel imaginario. Un estudio sobre los borbones en pelota," en Estudios de literatura española de los siglos XIX y XX. Homenaje a Juan María Diez Taboada (Madrid: CSIC, 1998), 38-46.

Calvo Maturana, Antonio, "Eva y la pérdida del paraíso imperial. Alegorías misóginas de María Luisa de Parma en el siglo XIX," Reales Sitios 67 (2006): 68-77.

Chastang, Théodor, Notice historique sur le château de Pau (Pau: 1869).

Cuadriello, Jaime. "Iconografía del 'contrapoder': resistencia, transgresión y conflicto," en La imagen politica. XXV Coloquio Internacional de Historia del Arte Francisco de la Maza', ed. Cuauhtémoc Medina (México: UNAM-Instituto de Investigaciones Estéticas, 2006), 21-22.

Fureix, Emmanuel, “La porte de derrière'. Sodomie et incrimination politique : des caricatures contre Cambacérès (1814-1815)," Annales historiques de la Révolution française 362 (2010): 109-130. 
https://doi.org/10.4000/ahrf.11704 consultado el 20 de mayo de 2019.

Lario, Ángeles, “Alfonso XII. El rey que quiso ser constitucional,” Ayer 52 (2003): 15-38.

file:///C:/Users/Admin/Downloads/alfonso-xii-el-rey-que-quiso-serconstitucional.pdf consultdo el 20 de mayo de 2019.

Méndez Paguillo, Jesús Carlos, "Caricaturas y revistas satíricas en la Sevilla del siglo XIX," Revista Internacional de Historia de la Comunicación 9 (2017): 1-36.

https://doi.org/10.12795/RiHC.2017.i09.01 consultado el 20 de mayo de 2019.

Merrick, Jeffrey. "The Marquis de Villette and Mademoiselle de Rancourt: Representations of Male and Female Sexual Deviance in Late Eighteenthcentury France," en Homosexuality in Modern France, ed. Jeffrey Merrick y Bryant T. Ragan (Oxford: Oxford University Press, 1996): 30-53.

https://doi.org/10.1093/acprof:oso/9780195093032.003.0003 consultado el 20 de mayo de 2019.

Mornat, Isabelle, "Masculino/femenino: estereotipos e inversiones en la caricatura española (siglo XIX)," 2014. <hal-01346438> https://hal.archivesouvertes.fr/hal-01346438 consultado el 20 de mayo de 2019.

Pageard, Robert, Lee Fontanella y María Dolores Cabra Loredo, eds., Sem. Los Borbones en pelota (Madrid: El Museo Universal, 1991).

Quesada Cañaveral, Julio, y Piédrola, Memorias del conde de Benalúa (Madrid: Blass S.A. Imprenta, 1924).

Regueiro Salgado, Begoña. "Los 'Borbones en pelota' y los Bécquer. Revisión crítica de su posible relación," en Campus Stellae. Haciendo caminos en la investigación literaria, ed. Dolores Fernández López y otros (Santiago de Compostela: Universidad, 2006), 206-213.

Rubio, Jesús, "En torno a la autoría y a la primera difusión de 'Los Borbones en pelota'," El Gnomo. Boletín de estudios becquerianos 3 (1994): 65-91.

Rubio Jiménez, Jesús, y Javier Urbina. "Imagen y política: el inquietante mundo de SEM," en Simposio sobre Literatura Popular 2011. Imágenes e Ideas: La Imaginatura (Valladolid: Fundación Joaquín Díaz, 2012), 104-188, https://funjdiaz.net/imagenes/actas/2011literatura.pdf, consultado el 20 de mayo de 2019

Troncoso, Dolores. "Napoleón III y España," en La fuerza del humor. Revistas satíricas del siglo XIX (Valladolid: Fundación Joaquín Díaz, 2013), 
https://funjdiaz.net/imagenes/catalogos/catalogo_satiricas.pdf, consultado el 20 de mayo de 2019

Vilar García, María José, "El primer exilio de Isabel II visto desde la prensa vascofrancesa (Pau, septiembre-noviembre 1868)," Historia Contemporánea 44 (2012): 242-279, http://www.ehu.eus/ojs/index.php/HC/article/view/6614/6052, consultado el 20 de mayo de 2019.

Recibido: 14 de enero de 2020

Aprobado: 4 de marzo de 2020 